\title{
WPS3409
}

\section{Corporate Governance and Enforcement}

\author{
By \\ Erik Berglöf \\ and \\ Stijn Claessens
}

\begin{abstract}
Enforcement more than regulations, laws-on-the-books or voluntary codes is key to effective corporate governance, at least in transition and developing countries. Corporate governance and enforcement mechanisms are intimately linked as they affect firms' ability to commit to their stakeholders, in particular to external investors. We provide a framework for understanding these linkages and how they are shaped by countries' institutional contexts. When the general enforcement environment is weak and specific enforcement mechanisms function poorly, as in many developing and transition countries, few of the traditional corporate governance mechanisms are effective. The principal consequence in these countries is a large blockholder, but there are important potential costs to this mechanism. A range of private and public enforcement "tools" can help reduce these costs and reinforce other supplementary corporate governance mechanisms. The limited empirical evidence suggests that private tools are more effective than public forms of enforcement in the typical environment of most developing and transition countries. However, public enforcement is necessary regardless, and private enforcement mechanisms often require public laws to function. Furthermore, in some countries at least, bottom-up, private-led tools preceded and even shaped public laws. Political economy constraints, resulting from the intermingling of business and politics, however, often prevent improvements in the general enforcement environment, and adoption and implementation of public laws in these countries.
\end{abstract}

World Bank Policy Research Working Paper 3409, September 2004

The Policy Research Working Paper Series disseminates the findings of work in progress to encourage the exchange of ideas about development issues. An objective of the series is to get the findings out quickly, even if the presentations are less than fully polished. The papers carry the names of the authors and should be cited accordingly. The findings, interpretations, and conclusions expressed in this paper are entirely those of the authors. They do not necessarily represent the view of the World Bank, its Executive Directors, or the countries they represent. Policy Research Working Papers are available online at http:/lecon.worldbank.org.

* Director, SITE, Stockholm School of Economics and Professor of International Finance Policy, University of Amsterdam, respectively. Both are Centre for Economic Policy Research Fellows. This paper was prepared for the Global Corporate Governance Forum, but the views are the authors and do not necessary represent those of the Forum or its donors. The authors owe Katharina Pistor many thanks for her extensive comments. They would like to thank the participants in a workshop on June 19, 2003 on Enforcement in Corporate Governance at the World Bank and participants in the workshop Enforcement during the GCGF High Level Working Meeting and Consultation on the OECD Corporate Governance Principles, November 2-4, 2003, Paris for useful suggestions. 


\section{Introduction}

Much effort in recent years has been devoted to the formulation of ever more elaborate and complete rules of corporate governance. Many countries have established sophisticated and extensive new legal texts and regulations, often imported from developed market economies, and adopted more informal codes of conduct. In addition to international efforts, such as the corporate governance principle of organizations like OECD, recent surveys have identified well over 100 national corporate governance codes adopted by various organizations (Gregory, 2000 and 2001). And one can add to this the seemingly endless corporate governance pronouncements by individual companies. These sets of rules, whether international, national, or company-specific, are all remarkably similar. Yet corporate governance practices differ substantially across countries and companies (see, for example, OECD, 2003). And there are still many concerns regarding the effectiveness of corporate governance rules in transition and developed countries, as well as many developed countries. In other words, the written rules are not adhered to and pronouncements of firms are not being followed up by actions. In great part this is because rules and regulations are not enforced and increasingly policymakers have come to realize that enforcement more than regulations and laws on the books is the key problem, at least in transition and developing countries.

The problem of enforcing agreements obviously extends far beyond corporate governance. Nobel Laureate Douglass North (1991) argued that "how effectively agreements are enforced is the single most important determinant of economic performance". Recent research supports this assertion, suggesting that enforcement of the rule of law is a, perhaps the, central functional difference between developed market economies and developing economies. Indeed, according to some analysis, the development of countries as well as their vulnerability to external shocks can be explained by the degree to which private property rights are being respected (Acemoglu, Johnson and Robinson, 2002). Comparisons between developed market economies and transition economies in Central and Eastern Europe also show much larger differences in 
enforcement (law effectiveness) than in laws on the book (law extensiveness) (Pistor, Raiser and Gelfer, 2001).

While enforcement is a general problem of development, it particularly affects firms seeking external financing. Financial contracts after all involve the commitment of the firm to adhere to certain obligations, in particular to pay an appropriate rate of return to the providers of external financing. A weak enforcement environment makes it more difficult for firms to commit to honor financial contracts and attract external financing. Again, it is not only the laws, but their enforcement that affects the ability of firms to attract external financing and, consequently, the degree of general financial development. Empirical evidence, for example, shows that it is not the presence of insider trading laws but rather actions taken against insider trading that help explain the development of securities markets (Bhattacharya and Durnev, 2001). ${ }^{1}$ A large international study finds that the level of enforcement is much more important than quality of laws on the book in explaining the turnover of CEOs (Defond and Hung, 2003).

Through its effect on commitment, a weak contracting environment also influences ownership and control patterns, and ultimately the functioning of the different corporate governance mechanisms. If commitment instruments are missing or weak, the typical corporate governance response is high ownership concentration. While ownership concentration can be the best individual response, and may indeed improve corporate governance, it also has many potential costs. At the firm level, these costs include entrenchment of the manager and owner, poor performance of firms, limited risk diversification and liquidity costs as the owner cannot sell its stake easily, and minority rights expropriation. At the country level, these potential costs risk undermining development of capital markets, with overall costs in lower growth, etc. High ownership concentration can also affect the development of corporate governance rules. Many, if not

\footnotetext{
${ }^{1}$ This is not to say that laws are not important, but rather that more than laws is needed. Lopez-de-Silanes (2003), for example, surveys the evidence on securities laws and enforcement and concludes that: "the development of capital markets depends crucially on laws that facilitate enforcement and the improvement of court procedures that allow for a more efficient dispute resolution."
} 
most, corporate governance systems in developing and transition countries are heavily tilted in favor of controlling owners, thereby potentially perpetuating any social costs.

The concentrated ownership structures also affect the effectiveness of other corporate governance mechanisms, and weaknesses cannot be rectified by laws and regulations (only). This discourages investors from taking controlling positions by adopting governance standards from developed market economies may lead to worse outcomes when other corporate governance are missing. Moreover, standards that are transplanted without sufficient domestic debate and adaptation are less likely to be adhered to or enforced. In the near term, corporate governance mechanisms in developing and transition countries have to function and reform has to be implemented in an environment where courts and other enforcing institutions are missing or very weak. The challenge is not to undermine perhaps the most potent corporate governance mechanism in less developed economies, concentrated ownership, while at the same time mitigating the potential costs that come along with these ownership structures. The solutions that are most likely to be effective will have to be mechanisms that rely less on public enforcement. These mechanisms and their effectiveness should be evaluated against the key corporate governance issue in emerging markets, finding the appropriate level of protection of (enforced) minority rights. Again, solutions should not (just) be laws on the books but rather solutions that encourage practices that matter most for corporate governance in these countries.

In this paper, we develop a framework to help understand when which corporate governance rules are (not) enforced and what can be done to improve corporate governance mechanisms in a weak enforcement environment. The analysis of various options should help understand which reforms, including corporate governance rules, are best pursued to improve corporate governance practices and mitigate social costs. The paper comes with its caveats. The literature on how to improve poorly functioning enforcement environments is large, in one sense it coincides with the literature on development. To summarize this disparate body of work in a short paper would be an 
insurmountable task. The paper instead focuses on enforcement issues as they relate to corporate governance.

We start by characterizing the general corporate governance problem and the functioning of the various corporate governance mechanisms in weak contracting environments. We then provide a typology of different forms by which each of these governance mechanisms can be strengthened. We consider several classifications. One distinction is between private and public mechanisms. Private initiatives can be outside of the legal system and can be unilateral, bilateral and multilateral. Separate from such private ordering among agents is private law enforcement, such as litigation by individuals. Laws can also be enforced through public means, when the government also acts as the prosecutor. And the government can have full control over all activities, in which case there are no property rights of contracts to enforce, and the laws are immaterial. We analyze the various enforcement mechanisms along this continuum. In the end, the most interesting question is why improvements in enforcement in corporate governance are so difficult to implement. Why do firms and countries, given the supposed benefits in terms of share prices and financing conditions, not adopt and adhere to the best possible governance standards? Even more puzzling, if there are such enormous returns to better enforcement, why do governments not invest more in enforcing? We provide some of these fundamentally political economy questions, but acknowledge that we have limited answers to date.

\section{The Corporate Governance Problem in Developing and Transition Countries}

The corporate governance problem in developing and transition countries is quite distinct from that of developed market economies. ${ }^{2}$ In this section we briefly define the problem with a focus on how a weak general enforcement environment influences the basic corporate governance mechanisms. To understand corporate governance and the role of

\footnotetext{
${ }^{2}$ For simplicity, we do not distinguish between developing and transition countries, even though the problems are often different in nature; for a discussion of the different corporate challenges facing developing and transition countries, see Berglof and von Thadden (2001). More recently, there has been some convergence, for example, in terms of ownership concentration (Berglof and Pajuste 2003).
} 
enforcement it is useful to start with a simple conceptual model of the firm and how it can be financed by outside sources. We then discuss how various mechanisms may be used to deal with the principal agent problems that arise because of the external financing (for more extensive overviews of the corporate governance literature, see Shleifer and Vishny 1997 and Becht, Bolton and Roell 2003).

An entrepreneur or manager approaching outside markets for finance faces a serious commitment problem: how can investors be assured that he will choose the right projects, exert sufficient effort, adequately disclose relevant information, and ultimately repay investors? In the complete absence of credible commitment, outside investors will assume the worst-case scenario, i.e., that the entrepreneur/manager will use all opportunities to defraud investors or in other ways not live up to his promises. The worse is the entrepreneur/manager's commitment power, the costlier will its outside financing be (and the more difficult it is to recruit good personnel and establish long-term supplier/customer relationships).

Corporate governance is in great part about mitigating this commitment problem. ${ }^{3}$ This is actually the definition of corporate governance advanced by Shleifer and Vishny in their 1997 review: "Corporate governance deals with the ways in which suppliers of finance to corporations assure themselves of getting a return on their investment" (1997, p. 737). Investors can reduce the likelihood of being defrauded or deceived by monitoring and potentially punishing management. Firms can try to employ a variety of commitment mechanisms to overcome investors' concerns.

\footnotetext{
${ }^{3}$ We consider here definitions of corporate governance that concern with the normative framework, that is, the rules under which firms are operating - with the rules coming from such sources as the legal system, the judicial system, financial markets, and factor (labor) markets. vary widely. We do not define corporate governance as a set of behavioral patterns, that is, the actual behavior of corporations, in terms of such measures as performance, efficiency, growth, financial structure, and treatment of shareholders and other stakeholders. The second provides of course input for analysis of corporate governance, and for studies of single countries or firms within a country, this definition is the most logical choice, but for comparative studies, the first definition is the more logical one. It investigates how differences in the normative framework affect the behavioral patterns of firms, investors, and others.
} 
Problems arise for two reasons: an individual investor may not have proper incentives to pay the costs involved in ensuring that the entrepreneur lives up to his promises and may attempt to free-ride on monitoring and enforcement by other investors; and the mechanisms to commit and punish may be missing or incomplete, possibly due to poor enforcement of property rights in the country. Typically the two problems will go together. When the costs of collecting information and enforcing contracts are high, as in many developing and transition countries, investors will find it more difficult to monitor and will thus be less likely to do so when there are many investors; and firms cannot commit credibly as institutions are missing or mechanisms are too costly to make seeking external financing attractive. These problems involve costs, in a narrow sense of some transaction costs and in a broad sense of lost firm and economic growth when some investment opportunities are not being financed.

Corporate governance is not only about mitigating the commitment problem, but often also about balancing the rights and interests of multiple stakeholders (i.e., management, the corporation, shareholders, creditors, employees and other stakeholders). Corporate governance is thus also structures in place that can help resolve the conflicts of interest among multiple stakeholders. Much of this resolution is ex-post, as when contracts were incomplete and did not foresee certain events. This resolution of conflicts of interest is different from the enforcement of property rights and contracts. It can actually involve the violation of ex-ante contracts or property rights. Bankruptcy is such an example, where absolute priority rules are sometimes violated in the interests of stakeholders. But these forms of corporate governance involve enforcement as well since the mechanisms that help resolve conflicts among certain stakeholders ex-post need to be enforced.

Bankruptcy also illustrates that conflicts within classes of stakeholders also are important for commitment. Bankruptcy law is primarily concerned with conflicts among creditors. While the interests of shareholders are generally viewed as being more aligned, through profit maximization, there are also important potential conflicts among shareholders in 
particular between large blockholders and dispersed, small shareholders. Corporate governance must also resolve these conflicts.

The two forms of 'enforcement' - enforcement needed to mitigate the commitment problem ("property rights") and enforcement of resolution mechanisms - while conceptually different are closely related in several ways. Weak property rights - because of unclear legal definitions of creditor and equity rights or poor and unpredictable enforcement — can imply that the scope for ex-post conflicts of interest problems is larger than otherwise. Poorly defined and enforced property rights can also mean that the mechanisms typically used to resolve conflicts of interest among multiple stakeholders are missing or weak as well. In turn, the large scope for ex-post conflicts of interest and the limits on the ex-post resolution mechanisms can complicate the ex-ante commitment problem. More generally, the combination of weak property rights enforcement and poor mechanisms for ex-post conflicts of interest resolution will often go together.

This combination need not be the case, however. Many countries may have weak ex-ante rules or poor property rights, but may have developed good ex-post resolution mechanisms. There have been studies, for example, showing that the probability of a CEO being forced out following bad corporate performance is equally high for countries with very different corporate governance regimes (Kaplan, 1994, Kang and Shivdasani, 1995 and Gibbons, 2003). What is clear is that a combination of poor enforcement of property rights and weak resolution mechanisms gives rise to "corporate governance" problems, in terms of lower capital markets development, less external financing, lower firms valuation and higher cost of capital, etc. (see survey by Claessens, 2003). We do not want to address the general issues of property rights definition and contract enforcement. For this, we refer to the general literature on enforcement (for a recent review, see Polinsky and Shavell, 2000). We try to address the second "enforcement" problem, defined as the resolution of conflicts of interest among multiple stakeholders 
using various mechanisms. Table 1 provides an overview of these mechanisms that can be used (see Becht et al., 2003 for a general review). 
Table 1. The Corporate Governance Mechanisms in Developing and Transition Countries

\begin{tabular}{|c|c|c|}
\hline $\begin{array}{l}\text { Corporate governance } \\
\text { mechanism }\end{array}$ & $\begin{array}{l}\text { Relative importance in developing and transition } \\
\text { countries }\end{array}$ & Scope for policy intervention \\
\hline Large blockholders & $\begin{array}{l}\text { Likely to be the most important governance } \\
\text { mechanism }\end{array}$ & $\begin{array}{l}\text { Strengthen rules protecting minority investors without } \\
\text { removing incentives to hold controlling blocks }\end{array}$ \\
\hline $\begin{array}{l}\text { Market for corporate } \\
\text { control }\end{array}$ & $\begin{array}{l}\text { Unlikely to be important when ownership is strongly } \\
\text { concentrated; can still take place through debt } \\
\text { contracts, but requires bankruptcy system }\end{array}$ & $\begin{array}{l}\text { Remove some managerial defenses; disclosure of } \\
\text { ownership and control; develop banking system }\end{array}$ \\
\hline Proxy fights & $\begin{array}{l}\text { Unlikely to be effective when ownership is strongly } \\
\text { concentrated }\end{array}$ & $\begin{array}{l}\text { Technology improvements for communicating with and } \\
\text { among shareholders; disclosure of ownership and control }\end{array}$ \\
\hline Board activity & $\begin{array}{l}\text { Unlikely to be influential when controlling owner can } \\
\text { hire and fire board members }\end{array}$ & $\begin{array}{l}\text { Introduce elements of independence of directors; training } \\
\text { of directors; disclosure of voting; cumulative voting } \\
\text { possibly }\end{array}$ \\
\hline Executive compensation & $\begin{array}{l}\text { Less important when controlling owner can hire and } \\
\text { fire and has private benefits }\end{array}$ & $\begin{array}{l}\text { Disclosure of compensation schemes, conflicts of interest } \\
\text { rules }\end{array}$ \\
\hline Bank monitoring & $\begin{array}{l}\text { Important, but depends on health of banking system } \\
\text { and the regulatory environment }\end{array}$ & $\begin{array}{l}\text { Strengthen banking regulation and institutions; encourage } \\
\text { accumulation of information on credit histories; develop } \\
\text { supporting credit bureaus and other information } \\
\text { intermediaries; }\end{array}$ \\
\hline Shareholder activism & $\begin{array}{l}\text { Potentially important, particularly in large firms with } \\
\text { dispersed shareholders }\end{array}$ & $\begin{array}{l}\text { Encourage interaction among shareholders. Strengthen } \\
\text { minority protection. Enhance governance of institutional } \\
\text { investors }\end{array}$ \\
\hline Employee monitoring & $\begin{array}{l}\text { Potentially very important, particularly in smaller } \\
\text { companies with high-skilled human capital where } \\
\text { threat of leaving is high }\end{array}$ & $\begin{array}{l}\text { Disclosure of information to employees; possibly require } \\
\text { board representation; assure flexible labor markets }\end{array}$ \\
\hline Litigation & $\begin{array}{l}\text { Depends critically on quality of general enforcement } \\
\text { environment, but can sometimes work }\end{array}$ & $\begin{array}{l}\text { Facilitate communication among shareholders; encourage } \\
\text { class-action suits with safeguards against excessive } \\
\text { litigation }\end{array}$ \\
\hline Media and social control & $\begin{array}{l}\text { Potentially important, but depends on competition } \\
\text { among and independence of media }\end{array}$ & $\begin{array}{l}\text { Encourage competition in and diverse control of media; } \\
\text { active public campaigns can empower public }\end{array}$ \\
\hline $\begin{array}{l}\text { Reputation and self- } \\
\text { enforcement }\end{array}$ & $\begin{array}{l}\text { Important when general enforcement is weak, but } \\
\text { stronger when environment is stronger }\end{array}$ & $\begin{array}{l}\text { Depend on growth opportunities and scope for rent } \\
\text { seeking. Encourage competition in factor markets }\end{array}$ \\
\hline $\begin{array}{l}\text { Bilateral private } \\
\text { enforcement mechanisms }\end{array}$ & $\begin{array}{l}\text { Important, as they can be more specific, but do not } \\
\text { benefit outsiders and can have downsides }\end{array}$ & Requiring functioning civil/commercial courts \\
\hline $\begin{array}{l}\text { Arbitration, auditors, } \\
\text { other multilateral } \\
\text { mechanisms }\end{array}$ & $\begin{array}{l}\text { Potentially important, often the origin of public law; } \\
\text { but the enforcement problem often remains; audits } \\
\text { sometimes abused; watch conflicts of interest }\end{array}$ & $\begin{array}{l}\text { Facilitate the formation of private third party mechanisms } \\
\text { (sometimes avoid forming public alternatives); deal with } \\
\text { conflicts of interest; ensure competition }\end{array}$ \\
\hline Competition & $\begin{array}{l}\text { Determines scope for potential mistreatment of } \\
\text { factors of production, including financing }\end{array}$ & $\begin{array}{l}\text { Open up all factor markets to competition, including from } \\
\text { abroad }\end{array}$ \\
\hline
\end{tabular}


The preferred mechanisms will depend importantly on the institutional development of the country, especially its contracting environment. It is therefore very difficult to generalize. Moreover, a potentially important corporate governance mechanism may be hard to influence through policy, or vice versa, a mechanism susceptible to policy intervention may not be very important. Ultimate policy recommendation should take both into account. A potentially important mechanism is the market for corporate control and the threat of a hostile takeover. An outside owner can take over the firm to correct management failure not disciplined by existing owners, and the mere prospect of such a hostile takeover could influence management even if it never happened. When hostile bids are not possible, e.g., new shareholders do not have sufficient resources to accumulate a large enough stake, they can hope that the company's board will become active, possibly even replacing incumbent management. If the board does not intervene or is ineffective, shareholders can pursue their interests in court, assuming of course that a court decision would affect what happens inside the firm. Small shareholders could also come together through the accumulation of votes or proxy fights. A shareholder can rely on holders of other claims, primarily creditors but potentially also labor when human capital is a critical asset to monitor and enforce contracts. Since holders of other claims may face collective action problems, they often delegate the tasks to one large actor, typically the bank, or sometimes the labor union can be effective.

These corporate governance mechanisms all depend nevertheless to varying degrees on the general contracting and enforcement environment in the country. Obviously, litigation is less likely to be effective when enforcing institutions are weak, but also other mechanisms are affected. Proxy fights require well-functioning shareholder registries, and markets for corporate control are hard to establish when shares are illiquid and the rights of outside investors uncertain. Bank lending is less likely to flourish when credit contracts are not enforced and collateral cannot be collected, or when banks are saddled with large stocks of non-performing loans or subject to a weak regulatory and 
supervisory framework. Still, as the enforcement environment improves, external finance becomes possible, typically in the form of bank and trade credit.

When the general enforcement environment of courts and other institutions is very weak, firms can choose to rely solely on internal funds or contributions from closely related investors. The literature normally does not talk about corporate governance in such closely held firms (as interests are supposed to be aligned). But if functioning corporate governance arrangements are not feasible, firms cannot even if they wanted, obtain outside finance and their growth will be constrained. Empirical evidence supports the negative impact of a weak contracting environment especially on the growth of SMEs and new firms (Beck, Demirguc-Kunt, and Maksimovic, 2003). Poor contracting environment also inflict large costs on owners, including limited risk diversification and poor liquidity for the inside investor.

The most common response to the free-rider and poor contracting problems is to give one shareholder a sufficiently large stake in the firm so as to provide him or her with incentives to monitor and intervene when necessary. In fact, the overwhelming majority of companies in developing and transition countries have highly concentrated shareholdings. Also in developed countries, however, many firms are closely held. Some controlling shareholdings have their origins in (individual or family-owned) firms growing large and accessing public markets while maintaining close control. But investors also respond to weak contracting environments by building up controlling stakes sufficiently large to provide proper incentives to monitor management. In countries in Central and Eastern Europe, for example, where initially shareholdings were widely dispersed deliberately, shareholdings have consolidated over the last five years to concentration levels exceeding those in Western Europe and comparable to those in many developing countries (Berglof and Pajuste, 2003). Concentrated shareholdings are often further reinforced as ownership is separated from control, primarily through pyramiding but in some countries also through cross-ownership and dual class shares. 
Large blockholders is a solution to some corporate governance problems. This large ownership does reduce the pre-commitment problem in one dimension since the demand of external financing is correspondingly less. Combined with control and a direct role in management, it also overcomes some of the principal agent and ex-post resolution problems. At the same time, there are important costs in various ways of ownership concentration, as documented extensively (Morck and Yeung, 2003 review). Needless to say, such delegation of authority gives rise to the problem of monitoring the large shareholder. The large shareholder may be entrenched and optimize private benefits rather than shareholder value, and engage in expropriation of minority shareholders through tunneling and other mechanisms. ${ }^{4}$

In weak contracting environments, nevertheless, controlling shareholders are most often the inevitable outcomes. Unlike many developed countries, notably the United States and United Kingdom, where the over-riding corporate governance conflicts are between powerful managers and widely dispersed investors, the main corporate governance conflict in developing and transition countries thus pits controlling shareholders against minority shareholders. Corporate governance policy in weak contracting environments has to strike a balance between the benefits of the controlling shareholders and the protection of minority investors. While many if not most corporate governance systems in developing and transition countries are heavily tilted in favor of controlling owners, wholesale transfer of governance standards from developed market economies may discourage investors from taking controlling positions and thus undermine perhaps the most potent corporate governance mechanism in less developed economies.

\footnotetext{
${ }^{4}$ While empire-building and excessive self-confidence of managers and controlling owners are likely to be the main sources of corporate governance failures in developed market economies, in weak enforcement environments preventing fraud becomes of paramount importance. Both developing and transition countries have seen systematic asset stripping, and tax evasion, by managers or controlling shareholders in large numbers of companies listed on exchanges. From an ex-ante point of view, the mere prospect of fraud has made it very difficult for companies to list on exchanges and raise outside funds, suggesting that actual costs of corporate fraud are much greater than suggested by the actual cases.
} 
The presence of large blockholders while inevitable in weak contracting environments will undermine the other corporate governance mechanisms. Both takeover bids and proxy fights against the desire of the controlling shareholder are less likely to succeed when shareholdings are concentrated. The market for corporate control will never materialize, as insiders cannot be challenged. Similarly, board activism is less likely to be successful in challenging the dominant owner, given that board members are appointed on his or her mandate. Executive compensation schemes are also less important as governance mechanisms, when controlling investors easily can intervene more directly and oust management. The middle column of Table 1 summarizes the above discussion of the effectiveness of these corporate governance mechanisms.

The basic insight of this analysis is that the priorities for corporate governance reform must take into account both the relative importance of a particular mechanism in a particular environment and the scope for impact of policy intervention in this environment. For example, in some environments where the court system functions satisfactorily, formal protection of minority shareholders enforced through private litigation is an option for improving the functioning of the key mechanisms of large shareholder monitoring. However, in weaker enforcement environments policy may have to focus on promoting private mechanisms and empowering shareholders through information dissemination. But ultimately the effectiveness of these other mechanisms will hinge on the general and specific enforcement environment. In developed countries, many firms are also closely held, yet minority investors do have some means to challenge the insiders, assure a reasonable rate of return on their investment, and thus are consequently willing to provide external financing. The last column of Table 1 provides some suggestions for reform for each corporate governance mechanism. In the next section, we will discuss the connection between the general enforcement environment and the specific enforcement mechanisms. 


\section{Enforcement: Specific Mechanisms}

Even though enforcement is generally agreed to be critically important to economic performance, and there is a vast literature on the subject, no simple framework for thinking about enforcement exists. We can consider several ways of classifying the issues related to enforcement. One distinction is between private and public mechanisms. Private initiatives to enforce contracts are critical to the functioning of any economy and can be outside of the legal system. These initiatives can be unilateral, bilateral and multilateral. Such private ordering among agents is different from private law enforcement. Law serves to standardize contracts and clarify liability. Laws can be enforced through private means, such as litigation by individuals, or by public enforcement. Under private law enforcement, private agents avail themselves of the framework defined by law or regulations to punish violations from contracts, using the courts to adjudicate and the state to enforce the final judgment. With public enforcement, the government not only provides the final enforcement system, but also acts as the prosecutor. In the extreme case, the government has full control over all activities, there are no property rights of contracts to enforce, and the laws are immaterial.

An enforcement system thus consists of a continuum of overlapping mechanisms ranging from private ordering via private law enforcement laws and government-enforced regulation to full government control (Djankov et al., 2003). All mechanisms have their costs and benefits and tradeoffs exist. Private and public initiatives are often complements, rather than substitutes. The effectiveness of private enforcement mechanisms often depends on the effectiveness of public enforcement mechanisms. Public enforcement brings down the costs of private enforcement. But while more public intervention may mitigate market failure, it is more vulnerable to government failure, and may not be the most efficient when private agents have better information, resources and incentives. Private agents are particularly important when the general institutional environment is weak. A system of social control of business is necessary in areas where 
both markets and government fail or cannot be expected to operate, and more generally is necessary to support the functioning of markets.

Another way to consider the issues is the degree and nature of the written laws (and regulations), which can be more or less extensive. Many laws are unwritten, so the question arises what needs to be codified in the first place, how codification varies

preferably by the level of development and social and economic features of the country, and how codification interacts with the various enforcement mechanisms. Presumably, very homogenous and close societies may still be able to rely on social means to enforce norms of behavior. But more development may mean more market-based economies and requiring more formality and codification. Second, the extensiveness of the law can affect the nature of the enforcement problem. Each law and regulation has its own optimal balance between the different mechanisms, blurring the distinction between written rules and their enforcement. With imprecise laws, private ordering and private enforcement may be costly or uncertain, and the benefits for parties to deviate may be too big. At the same time, broader laws allow for more evolution.

\subsection{Private Ordering}

Transactions can take place without the existence of courts and other public enforcing institutions. Actually, this private ordering has been the norm rather than the exception common historically and in many parts of the world. Greif $(1992,1993)$ provides historical examples of enforcement traders in the Mediterranean, and Ostrom (1990) gives illustrations from management of common resources in less developed societies. Ellickson (1991) discusses the protection property rights among cattle farmers in California. McMillan and Woodruff (2000) find evidence of private enforcement in the transition economy of Vietnam. Besley (1995) analyzes the protection of property rights for farmers in Ghana. Gambetta (1993) documents the role of the Sicilian mafia as a private enforcement arrangement. For a general review, see Dixit (forthcoming). We discus the different forms of private enforcement mechanisms as they relate to corporate 
governance and the scope for public policy in supporting these mechanisms. We distinguish as the literature generally does between unilateral, bilateral, and multilateral forms (e.g., Rubin, 1994).

Unilateral enforcement mechanisms involve efforts of individual firms to potentially improve their commitment power. A firm can through its own actions create valuable assets, which would be lost in case of violations of earlier agreements or standards. The most common unilateral mechanism is reputation, built for example through costly advertising. In the absence of a well-functioning general enforcement environment, unilateral actions can be important. For example, the Russian oil company Yukos was generously rewarded by the stock market when it unilaterally reformed its management and corporate governance. The actions presumably were credible because if the company, which before the campaign had a poor governance record, were to violate its professed principles, much of the investment would be lost (of course, it did not protect the company and its valuation from actions by the government as happened last year). Other unilateral forms include certain investment strategies, which only pay off if the firm continues to have access to external financing. A natural resources extraction firm may, for example, undertake a large investment with long gestation time and much sunk costs to signal its commitment to honoring current financial contracts.

The obvious problem with self-enforcement through reputation is that it relies on future interactions, e.g., that Yukos will have to come back to the stock market for more funding. Moreover, since the costs of building reputation are sunk, they may not deter future violations if the gains are sufficiently large. An additional problem of the reputation mechanism is that memory, particularly in stock markets, may be short. With losses to investors from previous violations already incurred and new investors coming into the market, considerations of new investments may not be affected by previous actions, thus weakening the commitment power of reputation in financial markets. 
In terms of bilateral mechanisms, two firms can strengthen their commitment ability in their interactions. Reputation of one party can play an important role in sustaining such bilateral enforcement arrangements. Yukos, for example, used the (expensive) consulting company McKinsey to reform, where McKinsey presumably would not have agreed to associate itself with the company had it not been convinced that Yukos was committed. Another means is through creating vertical or horizontal dependence by which one party can give up or share control over important decisions. A firm may also delegate some aspects of the business to a third party. Examples are plenty here, as in the separation of production and distribution in many industries which creates dependences and incentives not to deviate from commitments. Or, in order to avoid conflicts of interests credit allocation and risk management functions may be separated in a bank, which can enhance the overall quality of the lending process as each agent has less incentive to deviate from its assigned tasks and responsibilities.

Another form of bilateral mechanism is through investments. Control-oriented investment with one shareholder taking a large stake in a firm is one form of bilateral enforcement. ${ }^{5}$ Such structures are common in many business transactions. Many joint ventures, for example, are based on 50/50 control stakes. This may appear to be an ambiguous control structure, with much scope for conflicts among shareholders, especially when used in weak contracting environments. Yet the specific assets each partner brings in allows for optimal, bilateral private contracting and commitment (see Hauswald and Hege, 2003, for analysis of joint ventures).

The parties could also exchange "hostages", i.e., leave with each other's assets that are valuable to the provider but not to the party holding the hostage asset (in medieval times princes were supposedly used, assuming that they were primarily valuable in the country where the father was a king). It is more difficult to find specific examples of hostage exchanges that improve the corporate governance of firms towards outside, third-party

\footnotetext{
${ }^{5}$ This form of commitment relates to the boundary of the firm; in the presence of transactions costs, potentially due to a weak contracting environment, firms will more likely internalize transactions or create "conglomerates". Conglomerates or business groups can be thus be more common in weak contracting environments, although this raises its own set of corporate governance issues.
} 
investors. Hostage exchanges are difficult to arrange since the specific assets needed are in short supply and of less value for the outside investors. Some private shareholder agreements include covenants that are of a hostage nature, by for example, requiring some assets to be held offshore. Compensating cash balances and prepayments are sometimes mentioned as examples, but they are both highly symmetric in value and typically require some third party, like a bank or a court, determining whether the party can draw on the cash balance. Moreover, timing is critical, since the exchange preferably should be simultaneous. Bilateral mechanisms in general require some duration and reputation, and both parties should earn above market returns to sustain the mechanism.

For corporate governance by far the most important class of mechanisms is multilateral arrangements. Customs among multiple parties are established over time in repeated interactions or through learning across industries and jurisdictions, such as in guilds or other associations. Private parties can take the next step and establish institutions for collecting and conveying information about the adherence to these customs and erect credible punishments for deviations. Intermediaries may emerge exploiting economies of scale and profit opportunities, and preventing free-riding in enforcement.

Examples of such mechanisms abound. Trade associations adopt their own codes of conduct, and eventually also their own institutions for conflict resolution. In the financial sector, self-regulatory organizations are many: brokers associations providing licenses and overseeing conduct of brokers; investment banks establishing standards for underwriting; clearing houses and payments systems organizing settlement and payment services; and associations of banks and other financial institutions developing rules for conflicts of interest, exchange of information, etc. Intermediaries like business organizations sell information and thereby develop rules and standards, while rating agencies and other organizations for quality monitoring collect data, establish standards and disseminate information. 
Stock exchanges in turn develop listing requirements. These organizations develop norms for interactions among members, with mechanisms for punishments. Clearing houses, for example, need to be able to expel members to function properly. Commercial and investment banks can certify and monitor firms in the context of lending and underwriting activities. Since they engage in multiple relationships, they can act as a multilateral enforcement mechanism. Private arbitration is another form of multilateral mechanism where parties sign up to a mechanism that has some commitment power as it is involved in repeated interactions. Ultimately though, some form of public intervention enforcement may be necessary to enforce private arbitration.

Private enforcement mechanisms, multilateral arrangements in particular, face a number of challenges. Actors should generally be expected to behave opportunistically whenever it pays. The more parties are involved the harder it is to sustain such collaboration, unless it is supported by some form of public actions. At the same time, a small number of actors can lead to entrenchment and weaker (corporate governance and others) standards. This is particularly so in small markets where self-regulatory associations and organizations have often not been successful as they maintained low standards and engaged in rent-seeking behavior. Some degree of competition can help limit opportunistic behavior, although this is not guaranteed (as recent events in competitive financial markets in developed countries have shown). Reputation is also important in sustaining bilateral and multilateral arrangements, but often difficult to establish as multiple equilibria can arise. When reputation is low in general, as in many developing and transition countries, few transactions can be sustained. Thus there are fewer opportunities to build reputation. Moreover, the uncertainty so pervasive of developing and transition economies reduces the value of future rewards for good behavior today. As consequence, moving out of a low-reputation equilibrium is hard.

How effective are private mechanisms - unilateral, bilateral or multilateral - in bringing about change in enforcement of good governance practices? Black (2001) provides some suggestive data from Russia indicating that individual firms, even in a poorly functioning 
environment, can increase their value substantially by improving their corporate governance unilaterally. Similar evidence exists for Korea (Black, Jang and Kim, 2003), but as with the Russian study serious causality and other methodological problems weaken the power of these tests. The entry of foreign firms normally adhering to higher governance standards can also help. Cross-border mergers and acquisitions have been found to originate from countries with higher corporate governance standards and to be aimed at countries with lower standards, thereby potentially improving corporate governance (Rossi and Volpin 2003). There is also a tendency, however, for foreign investors to adjust to or even misuse the local corporate governance environment, as shown by some corporate governance scandals involving foreign investors from developed countries taking over firms in developing and transition countries. Even if incentives are weak for individual firms, foreign (and domestic) entry and competition may nevertheless help put pressure on local firms to improve their corporate governance.

The effectiveness of all of these private enforcement mechanisms in the area of corporate governance does, however, depend on the general institutional environment. Private arbitration, for example, is more likely to be effective when courts and enforcing agencies work well. In work on Korea, Black, Jang and Kim (2003) show that private mechanisms often are not sufficient, but need the support of government intervention. Evidence from Durnev and Kim (2003) and Klapper and Love (2003) show that by improving their own corporate governance individual firms cannot compensate fully for deficiencies in local governance practices.

Given efficiency and incentive considerations, private enforcement mechanisms will nevertheless need to be the main corporate governance mechanisms in most markets. This will be even more so in countries with severe weaknesses in public law and public enforcement. Furthermore, in one view, public law emerges out of private ordering, at least in common law systems; courts "find" well-functioning contractual arrangements among parties and elevate them to law (Cooter, 1991). A related view applied to securities law in the United States suggests that private parties adopt rules, which later 
are adopted by individual market places and eventually become laws or regulations (Coffee, 2001).

\subsection{Private Law Enforcement}

In most societies, it is largely private initiatives that help enforce existing laws and regulations. The government creates the rules governing private conduct but leaves the initiation of enforcement to private parties. When a party feels cheated, he or she could initiate a private suit and take it to the court or other agency. Private enforcement is more likely to work and cheaper if the law has mandated a certain standard. It may then be easier to initiate and prove a case than if courts have to rely on general principles. The burden on the courts and the plaintiff of proving liability or lack of liability is reduced if statutes specify what facts need to be established. Well-defined statutes may also reduce the discretion of judges and undermine attempts to subvert the law. Private law enforcement may be particularly efficient in situations with weak or ill-experienced courts (Black and Kraakman (1996) and Hay, Shleifer, and Vishny (1996)).

In the area of securities regulation, private law enforcement seems highly effective for capital markets development, while public enforcement seems less important (La Porta et al., 2003). As many elements of securities regulation involve issues related to corporate governance, this may apply to enforcement of corporate governance more generally (Lopez-de-Silanes, 2003 reviews). For private enforcement to be effective, however, agents must have incentives. For many of the corporate governance issues related to securities markets, stock exchanges have appropriate incentives, to check for example, whether firms adhere to listing standards (although there are concerns about a race to the bottom and there needs to be competition among stock exchanges or at least for the services stock exchanges provide). For many other corporate governance issues, this will not be the case. Individual shareholders will have fewer incentives to litigate due to the free-riding problems, although class-action suites can overcome this (with the caveat that it can lead to frivolous law suits). 
Needless to say, the society needs institutions that can impose sanctions for private law enforcement to work. This can be a court and a judge, but also other institutions.

Governments, for example, often "delegate" enforcement to lower levels of government or self-regulatory agencies or authorities (SROs). Much of the implementation of rules for say obtaining a business license and accompanying appeals is delegated to semigovernment agencies. Licensing for many professions, such as medical doctors or lawyers, are delegated to respective own associations. In financial markets, many SROs derive their status and ability to regulate financial markets transactions from public law. A stock exchange, for example, may be granted a natural monopoly and thereby have the explicit and implicit powers to regulate securities markets activities, although it may not be a government agency itself (and typically would not be so).

These forms of delegated enforcement may work better if the subsidiary body has more specific information, better resources and a broader range of sanctions. Local agencies may for example, be better able to judge the quality of the application for a business license. SROs may, for example, have greater insights in what constitutes market manipulation and have more information system to detect such behavior. SROs may also be able de-license, issue a reprimand (name and shame), as well as impose financial sanctions, action which may be more difficult for a government agency. Nevertheless, these agencies will needs some backing up from higher levels of government or from the judicial system.

\subsection{Public Enforcement}

The literature on how to improve public enforcement is large. This section focuses on a three issues in this literature, as they relate to corporate governance: the interrelationship between the extensiveness and effectiveness of law; the positive theory of enforcement and the efficiency and effectiveness of enforcing institutions; and the relationships between laws, corruption and enforcement. 
In the simplest possible characterization the written law has no independent function, the only thing that matters is what part of laws and regulations are actually enforced. Others argue that this dichotomy is too simple: the written law can be more or less extensive, and enforcement more or less effective. Some laws are also more easily enforced than others, suggesting that the enforcement environment may shape what laws are desirable and that how the law is written may in turn influence the scope for enforcement. In this view we have a two-by-two matrix with rudimentary vs. extensive corporate governance rules and weak vs. strong enforcement. A related view distinguishes between low and high legal standards, where the distinction more relates to the threshold set for violating the law.

A large literature has documented differences between the extensiveness of law, i.e., the scope and detail of the law, and effectiveness, i.e., the extent to which the law is actually enforced. Pistor and Xu (2003) apply this concept empirically and found that it helps predict choices between regulatory and legal approaches to financial markets regulation. A closely related body of work discusses the choice between very detailed, highly nuanced rules, and simple, easily understood and interpreted, rules (co-called bright-line rules) (Glaeser and Shleifer, 2002).

There is the general economic literature on enforcement, inspired by Gary Becker's (1968) provocative article suggesting that maximizing punishment would ensure optimal enforcement. Later contributions have emphasized the constraints imposed on fines by the liquid assets available to those punished. Others have pointed to the (exogenous) limits to enforcement technology. These analyses have provided some insights on the factors affecting enforcement technology and the choice among enforcement technologies.

The efficiency and effectiveness of technologies and enforcing institutions such as courts, stock exchanges, SROs and the like, are, however, hard to study empirically. Efficiency 
normally refers to outputs relative to inputs, but both outputs and inputs are difficult to measure. In evaluating the efficiency of courts, we are normally concerned not only with timeliness, i.e., how fast cases are processed, but also with access to the court (e.g., for the poor), fairness, and predictability. Effectiveness may in some cases be the overriding objective, e.g., in some cases very large sums are justified to ensure that the outcome is just or right. The Microsoft anti-trust case has cost millions of dollars, but it may have been worth it given its large implications. It also matters how cases are managed, i.e., what input is entered when. Input efficiency involves assessing the type of funding and incentives provided. Ultimately, court output must take into account overall "customer satisfaction", i.e., do citizens trust the legal system. Furthermore, an analysis of court efficiency needs to extend beyond the courts themselves to understand their role in the larger legal system. So far, few empirical analyses exist.

There is a specific literature on the importance for enforcement of regulators and supervisors that are independent, have adequate powers, are well-staffed and have operational and financial functional independence. This has been found for central banks and other agencies, such as competition policy agencies and regulatory agencies. The financial and operational independence can be particularly important. In many countries, securities exchange regulators have their own sources of income (by collecting fees from new issues or trading), yet they have to transfer some part to the general budget or otherwise have to get their budget approved by the parliament or other government agencies, thus reducing their de-facto independence. At the same time, there can be limits to the benefits from stronger regulators and supervisors in weak institutional environments such as in many developing countries. Perverse effects may arise from more legal powers in environments with relatively low pay for regulators and supervisors, and weak checks-and-balances (as highlighted by Barth, Caprio and Levine, 2000). In such environments, more powers may simply invite more corruption. 


\section{The Choice of Enforcement Technologies and the General Environment}

\subsection{The Choice of Enforcement Technologies}

The preferred mix of enforcement technologies will vary by type of activities and by country characteristic (next section). In some areas, social norms will serve as the first enforcement technology with the more formal system as a second resort. Media can play a potentially important role in "enforcement," both nationally and locally, although they may not use any legal tools. Threats of revolts by store-costumers against a large paypackage for the new manager of the Dutch grocery chain Albert Heijn led the paypackage to be reduced and the chairman of the board of directors of the group (Ahold) to resign. In many ways, these social pressures will be the most important corporate governance mechanisms. They do in turn require a relatively free media and access to newspapers. Here technology can help, as in Korea where much of the concerns on corporations' activities have been shared through the Internet.

The role various formal enforcement technologies will play in a particular sector or activity will in part depend on the relative costs and benefits of the technologies. The existence of cheaper outside options, for example, will affect the use of courts versus other enforcement technologies. The use will also depend on the extent to which one enforcement technology requires the backing of another technology to make it credible and assure finality of decision. Activist movements, like shareholder lobbying group, do require some legal backing (Milhaupt, 2003). Regulatory intervention in the corporate governance area will typically not fully resolve the basic commitment problem and will require some backing of the court system for appeals and enforcement (say insider trading pursued by the stock exchange requires the backing of the sanctions of an SEC). An important corporate governance mechanism is monitoring by banks, but the development of bank lending and monitoring obviously relies on the effectiveness of the regulatory framework and supervision, in addition to the other institutions for public enforcement allowing collateral to be collected. 
To a certain extent, cost-benefit considerations can explain the choices among enforcement technologies. Path dependence is, however, also important: an enforcement technology may be introduced and then remain used for a long time, even though other more efficient technologies have become available. For example, collateral and its registration is a form of contract enforcement. These days, it can more easily be registered and consequently perfected using electronic, dematerialized registries than using expensive courts or notary-based systems, but the transition often takes time and institutional reluctance may have to be overcome. Technological progress can change this, but typically only slowly. Securitization, the sale of many assets bundled together, for example, became possible because of information technology progress, which allowed secondary asset sales while assuring that the underlying contracts remain identifiable and could be enforced.

Most importantly, each country will choose a different mix of technologies. Clearly, for many developing countries the optimal mix of technologies will differ from what we observe in developed countries today. Public enforcement can only play a limited role in weak institutional environments, as powerful controlling owners and managers will most likely find their way around the system. Private enforcement of public laws and the power of litigation and court intervention vary greatly across countries depending on the functioning of the public enforcement institutions. Russian investors, for example, almost never go to courts, because when they do so, the likelihood of success is miniscule and even if they win a judgment in their favor is often not enforced (Zhuravskaya and Zamulin, 2003).

With weaknesses in courts, other enforcement mechanisms maybe used more in trying to enforce good corporate governance. Policies promoting bank lending and financial development may, for example, then help to enforce corporate governance. Yet, even here relative costs are important. In China, investors became increasingly active in taking their grievances to court although court decisions were not always predictable or 
necessarily enforced (Pistor and Xu, 2003; and Xu and Pistor, 2003). ${ }^{6}$ The reason is that other mechanisms are even more costly or absent; the banking system, for example, is little reformed.

\subsection{The General Enforcement Environment}

Much of the choices between the various technologies will depend on the overall environment. A number of interrelated factors are likely to influence the general enforcement environment of courts and other enforcing institutions (Slinko, Yakovlev and Zhuravskaya, 2002): the incentives of national and local authorities, political competition at various levels of government, and the strength of civil society. These aspects will not only vary across countries, but also across regions and municipalities within a country. In Russia, Brazil and Mexico, for example, large differences exist in enforcement among states or provinces (Broadman, 2000, Pinheiro Castelar, 2001; Laeven and Woodruff, 2003). Furthermore, where markets function poorly, the legal system is generally weak. Conversely, competition in product markets, by affecting the scope for capture, and the size of the small-and-medium-sized-enterprise sector can affect the functioning of courts.

Endowments and distribution of natural resources and technology also matter for the institutional development of countries, including the degree of public enforcement. Relationships have been found between institutional features and countries' more permanent characteristics, including culture, history, and physical endowments.

Institutional characteristics such as the risk of expropriation of private property can be long-lasting and relate to a country's physical endowments (Acemoglu, Johnson and Robinson 2003 show this for a cross-section of countries). The historical origin of the legal and general institutional system, whether English, French, German, or Scandinavian, and the corresponding basic legal mechanism, whether common law or civil law, seem to matter for enforcement (LaPorta et al., 1997, and 1998). While the

\footnotetext{
${ }^{6}$ After the onslaught of litigation, the Chinese Supreme Court basically froze the process by stating that it did not have the competence to adjudicate these cases. Recently, litigation activity has again surged.
} 
differences in the functioning of legal systems have decreased over time, the various systems still differ in terms of the balance between private and public rules and still correlate with the degree of general enforcement. Similarly, wholesale transplants are largely ineffective in the diffusion of governance practices (Berkovitz, Pistor and Richard, 2003).

The quality of the general enforcement environment affects the functioning of legal mechanisms specific to investor and creditor protection. Only a combination of strong investor rights and an efficient judicial system leads to a well-developed financial markets. More recent research shows that both a country's initial endowments and the origin of its legal systems are important determinants of the degree of private property rights protection (Beck, Demirgüç-Kunt, and Levine 2003).

The general enforcement environment is not only the product of many different market, endowment and legal factors, but also of social and cultural factors. Enforcement will depend on basic social norms and trust (Djankov et al. (2003) denote this "civic capital"). When societies are socially and culturally heterogeneous, the base for natural forms of enforcement is typically weaker. This is clearly true at the micro level. The ability to have well-functioning rotating saving schemes, for example, greatly depends on the presence of close relationships and homogenous groups. But it also seems true at the country level. The roles of culture and openness have been found to be important for financial sector development, including for corporate governance (Stulz and Williamson, 2003). As societies develop, and undergo both economic and social transformation, the nature and forms of enforcement are likely to change towards more formal modes of enforcement.

Political institutions are part of the general enforcement environment. ${ }^{7}$ Political institutions may not function well and can be dominated, for example, by an absolute

\footnotetext{
${ }^{7}$ Political institutions can be evaluated based on several criteria: how well represented the views of the electorate are in the institution, the extent to which politicians and bureaucrats are accountable to their constituencies and to each other (vertical and horizontal accountability,
} 
ruler or captured by special interests. In both cases, serious enforcement problems can result. Countries with absolute rulers will have many public governance issues, including the protection of property rights against interference by the dictator. These countries may have fewer corporate governance issues, however, as there will be few genuine "market" transactions. The other set of countries are those like many emerging markets where business and politics tend to merge. When large controlling owners become politicians, an important countervailing force to government is lost, and the interests of minority shareholders are less likely to be protected. When the rich influences the path of justice, litigation does not work (Glaeser, Sheinkman, and Shleifer, 2003). When enforcing institutions are corrupt, the level of enforcement may be endogenous (Acemoglu and Verdier, 2000). Corruption lowers enforcement effectiveness by increasing the costs of motivating and monitoring bureaucrats.

As noted already, legal standards and the level of enforcement can interact. In the general enforcement context, corruption may affect how laws are written (Immordino and Pagano, 2003). Governments may respond to weak enforcement by formalizing through codes to reduce discretion and opportunities for subversion of law, but this can have its own costs. Stricter laws and regulations offer more incentives to evade, and thus are more costly to enforce than others. In the model of Immordino and Pagano, a benevolent government trades off the benefits of stricter legal standards with the costs of their enforcement. With a benevolent government, standards should be set lower, because the costs of enforcing them are higher. In other words, legal standards and enforcement are complements, and as countries develop both can increase. In practice, this tradeoff between strictness of the laws and incentives to evade has be used in the debate on accounting principles, where the choice has been between International Accounting Standards, which are more principle-based, and US FASB-norms, which are more detailed, rule-based.

respectively), whether certain positions are appointed (from above) or elected (from below) (bureaucratic vs. democratic accountability), and, closely related, their independence from each other (Persson and Tabellini, 200X; and Berglof et al., 2003). 
Laws and regulations could not only be adopted to correct market failures, reduce transactions costs and achieve social objectives, but also to extract bribes. Djankov et al. (2002) find some support for this so-called tollbooth view, especially in less developed countries, suggesting to err on the side of less strict laws in weaker environments. The work of Barth, Caprio and Levine (2003) supports this for bank regulation and supervision as more powers to bank supervisors lead to less efficient and more unstable financial systems in environments with limited checks and balances. Immordino and Pagano (2003) provide evidence that even governments in developing countries actually rationally adopt lower standards, as the costs of enforcement are higher.

\section{Corporate Governance and Enforcement}

Private ordering, private law enforcement and public enforcement all have a role in influencing the overall effectiveness of the corporate governance system. While we have discussed the different sets of mechanisms separately, they do overlap and can both substitute for and reinforce each other. To evaluate how the various options interact, we need to go back to the main corporate governance problem in developing and transition countries as summarized in Table 1. As noted, the overriding corporate governance problem in emerging markets is about balancing incentives for controlling shareholders and protecting minority rights against actions by insider shareholders. Different mechanisms can be used to address these and each needs different enforcement tools.

Table 2 shows how different forms of enforcement can help reinforce the basic corporate governance mechanisms identified in Section 2. We note that the figure does not attempt to be comprehensive, rather it aims to illustrate by use of example the specific enforcement technologies that can be used to enhance their effectiveness. 
Table 2. Corporate Governance Mechanisms and Enforcement

\begin{tabular}{|c|c|c|c|c|}
\hline & \multicolumn{4}{|c|}{ Enforcement tool } \\
\hline Corporate governance mechanism & Private ordering & Private law enforcement & Public enforcement & State control \\
\hline Large blockholders & Natural consequence of weak enforcement & (Minority) shareholder suits & $\begin{array}{l}\text { Governance codes evolving into corporate and } \\
\text { securities law }\end{array}$ & $\begin{array}{l}\text { State ownership or golden } \\
\text { share to mitigate social costs }\end{array}$ \\
\hline Market for corporate control & & & $\begin{array}{l}\text { Corporate law: defenses, procedural rules; } \\
\text { transparency of ownership and control }\end{array}$ & \\
\hline Proxy fights & & & $\begin{array}{l}\text { Improve communication technology; Allow vote } \\
\text { by mail }\end{array}$ & \\
\hline Board activity & $\begin{array}{l}\text { Facilitate interaction among board members, } \\
\text { training of independent directors }\end{array}$ & & & \\
\hline Executive compensation & Transparency rules of stock exchanges & & Transparency rules & \\
\hline Bank monitoring & Credit bureaus, registries, reputation & & Protection of collateral; bankruptcy reform & \\
\hline Shareholder Activism & No ownership limits & & $\begin{array}{l}\text { Require disclosure of the voting and positions of } \\
\text { institutional investors }\end{array}$ & $\begin{array}{l}\text { Encourage public pension } \\
\text { funds to be more active }\end{array}$ \\
\hline Employee monitoring & Encourage labor flexibility & & & \\
\hline Litigation & & $\begin{array}{l}\text { The key mechanism for } \\
\text { private enforcement }\end{array}$ & $\begin{array}{l}\text { Governance codes adopted by exchanges and } \\
\text { others which have a "charter" provided by law }\end{array}$ & \\
\hline Media and social control & Deregulate media to allow freer competition & & & $\begin{array}{l}\text { Provide more information } \\
\text { through public media }\end{array}$ \\
\hline Reputation and self enforcement & $\begin{array}{l}\text { Depends on growth opportunities and degree of } \\
\text { rents }\end{array}$ & & & \\
\hline $\begin{array}{l}\text { Bilateral private enforcement } \\
\text { mechanisms }\end{array}$ & $\begin{array}{l}\text { Hostage and shareholders agreements. Require firm- } \\
\text { specific assets }\end{array}$ & $\begin{array}{l}\text { Establish specific control } \\
\text { rights under contract law }\end{array}$ & & \\
\hline $\begin{array}{l}\text { Arbitration, auditors, other } \\
\text { multilateral mechanisms }\end{array}$ & $\begin{array}{l}\text { Arbitration to resolve conflicts. Other third parties } \\
\text { (auditors, rating agencies, stock exchange listing } \\
\text { requirements, foreign listings; formation of trade } \\
\text { organizations; corporate governance codes) for } \\
\text { reputation, signaling, standardization of norms. }\end{array}$ & & & \\
\hline Competition & Greater competition in all factor markets & & & \\
\hline
\end{tabular}


Large shareholders. When the general enforcement environment is weak, external finance is costly, resulting in ownership concentration. Controlling shareholders are thus a feature of weak environments, and any attempt to improve corporate governance will have to take this into account. Large shareholders will act in their own interests and can pursue private benefits, rather than increasing overall firm value or minority shareholders' rates of return. State-ownership or golden shares can in some circumstances be a means to deal with the social costs of weak enforcement settings.

The market for corporate control will be correspondingly less active, making hostile takeovers less effective and proxy fights more difficult to win. Hostile takeovers are not completely impossible, however. In Russia, for example, investors have found ways to exploit financial distress and using bankruptcy rules to topple incumbent owner-managers (Guriev et al., 2003). Whether this is leading to efficient outcomes is still to be seen, but it shows that some elements of a market for control are working.

Since the owners appoint boards, little independent corporate governance should be expected from the board in a firm with a controlling owner. Requiring independent directors will have limited direct effect, as the controlling shareholder will not allow for any real influence on a firm's board. Nevertheless, requiring some degree of independence from some directors could still be important. For example, independent directors can play an important role in transferring knowledge at the level of the individual firm and building constituencies for corporate governance reform at the country level.

Executive compensation schemes will not play the same role in decision-making as it does in firms with more dispersed ownership structures given that the controlling owner can hire and fire managers at his own discretion. Furthermore, the controlling shareholder will typically have many other means to "reward" himself. Disclosure of executive compensation schemes is nevertheless a good thing, even when they are not the key motivating force in managerial decision-making, as general public pressure may help restrain some forms of dilution. More 
generally, transparency promotes an informed discussion of corporate governance both at the firm and country level.

Banks as lenders and monitors. Lending and monitoring by banks, typically the most important source of external finance, is of particular interest. As lenders, banks will have a direct stake in the governance of corporations, requiring firm behavior that assures that their loans can be repaid. As monitors, banks can compensate for some weaknesses in the general enforcement environment as they have repeated dealings, have reputation to maintain in lending, and can economize on monitoring and enforcement technology. The development of bank lending itself obviously relies on the effectiveness of the regulatory framework and supervision, in addition to other institutions allowing collateral to be collected. As such, public enforcement is still a necessity.

Shareholder activism groups can be important. These have been in existence in United States, United Kingdom, Korea, Japan, and many other countries. As shown by Milhaupt (2003) in an analysis of shareholders groups organized as non-for-profit organizations in Korea, Japan and Taiwan, the effectiveness of such groups can vary depending on issues such as their funding structures, the non-distribution of awards and whether they seek to use and improve existing local enforcement institutions or abandon those.

Employee monitoring can be an effective mechanism to enhance corporate governance as its interests are largely aligned with good firm performance and fair treatment of all stakeholders. For this mechanism to be powerful, employees must be mobile, however, in order to credibly threaten to leave the firm. More generally, effective competition in all factor markets will help improve firm's corporate governance. Increased competition in output markets not only puts more pressure on the firm to enhance its performance, but also increases the premium to better corporate governance to be able to attract the necessary financing to invest and survive.

Litigation can neither be expected to be a good governance mechanism in weak contracting environments. Litigation is, however, still less dependent on government actions than public 
enforcement is, as it is a private enforcement of public laws. As shown by La Porta, Lopez-deSilanes and Shleifer (2003), private enforcement works relative better in securities markets than public enforcement does, especially in less developed countries. And litigation can help develop the standards against which corporations know they will be judged and which may eventually evolve into law.

Media and social control often play an important role in disciplining managers and controlling owners (Dyck and Zingales, 2003). In a narrow sense, in improving the access to information and reducing the costs of monitoring, and in a broader sense in making corporate governance an issue of public debate. In countries like Korea, corporate governance became a household word thanks in part to wide media coverage of corporate sector abuses. In turn, regulation and other efforts promoting plurality in media could have a strong impact on the enforcement of good corporate governance.

Reputation. When ownership and control in individual firms are concentrated because of weak enforcement, reputation mechanisms can still be of value for large shareholders as they need to raise outside funds, but minority shareholders should not expect too much from formal governance mechanisms.

Bilateral private enforcement mechanism. Most private agreements are bilateral. In order not to be renegotiated ex post when there is no enforcement, they require firm-specific assets and in any case they need not benefit other shareholders. Nevertheless, bilateral agreements may be valuable (to blockholders) even in the absence of firm-specific assets. While they also suffer from the weaknesses in the general contracting environment, agreements between blockholders and the controlling shareholder, that may cover board representation, access to information, permission for changes in control rights, and procedures for approving related party transactions, can add value. Because they include more specific covenants, they may overcome some incompleteness in the existing legal system and can be more easily judged by inexperienced courts. Also, the general court system dealing with civil cases may be better than the specific court dealing with capital markets transactions. In many developing and transition countries, for 
example, civil courts function relatively well, but courts to deal with capital markets transactions are not well equipped. In case of such “arbitrage” opportunities, shareholders' agreements can add value to blockholders. They are of little value, however, for small shareholders.

Multilateral private ordenings. For joint ventures or international investments, arbitration can help in enforcement as it can rely on tools such as the New York Convention that makes international arbitration binding in the local context (although it still requires some degree of local enforcement). Arbitration is of less value domestically when the general enforcement environment is weak as backup and appeal procedures are missing. Only in markets with repeated dealings and a small number of participants might arbitration still work well.

Stock exchanges' listing requirements are another multilateral tool. Examples of stock exchanges' efforts to raise corporate governance are the Novo Mercado in Brazil where higher corporate governance standards in a new market are combined with an arbitrage system. Provision of such voluntary standards that corporations can adhere to can be useful, although they do require some enforcement. Their effectiveness depends on the "franchise value" of the exchange: if the exchange is a (local) monopoly, it may have more enforcement power. (At the same time, the stock exchange may be less interested in corporate governance reform.) In other markets, listing rules from stock exchanges are forcing corporations to reform or risk delisting and seeing their access to public markets' financing disappear. Still, the effort needs to improve over other options for firms to signal higher corporate governance standards, such as using international markets. Foreign listings can be a bonding device, as they involve some costs to adhere to higher standards. Some_- Licht (2002) in general and Siegel (2004) for the case of Mexico-note, however, that the SECs of host countries often do not take actions against minority rights violations committed at home. As with the general findings for securities markets, listing abroad may help more through private enforcement of exchange listing requirements, particularly disclosure, and only for some aspects of public laws. 
Other third parties can help by bonding. Accountants and auditors can signal the quality of a corporation and some its corporate governance aspects if they have some reputation to lose. The scope for improvement through the role of accounting and auditors will, among others, depend on the local standards used in accounting and auditing, and the legal liabilities for misrepresentation. Furthermore, these firms can suffer from conflicts of interest if they have other, say consulting business with the same firm. Investment banks can signal quality of firms in the process of underwriting public offerings, although they too can suffer from conflicts of interest lowering the value of the signal. Rating agencies assess firms in general for bond and loan ratings, which includes some assessment of firms' corporate governance. More recently, specific corporate governance ratings of firms have been produced, by the traditional rating agencies and others. These ratings can coordinate information collection, establish standards, and be a source of bonding when rating agencies have reputation to protect. The ratings are new and they have yet to show their value, but they could be particularly useful for institutional investors that cannot incur the costs of assessing the corporate governance of individual firms.

Corporate governance codes and other standards. As with corporate governance ratings, codes can coordinate information collection and establish standards. Stock exchanges can use them as part of their listing requirements ("comply or explain"), thus given some enforcement power to the codes. Codes can also have an indirect value if they lead to the codification of laws. Yet, they are no enforcement by themselves and need to be used by investors and others to lead to changes in the behavior of corporations.

\section{The Political Economy of Enforcement}

Ultimately, the effectiveness of many enforcement mechanisms hinges on the commitment from the political sphere to enforce existing laws and regulations. Given the enormous potential gains from improvements in public enforcement building support for reforming these institutions should be easy. In particular, enforcement institutions should be easier to reform than changes in basic investor rights where there often are clear winners and losers. But many attempts to reform 
investor rights have failed because of powerful opposition. In Brazil attempts to revoke the right to issue and maintain non-voting shares were unsuccessful, as they would have reduced value for the voting, controlling shareholders (Nenova, 2001). In Thailand senators blocked bankruptcy reform, as they were also major owners of distressed corporations (Foley, 2000). Furthermore, to change investor rights many hurdles need to be passed; in some countries, changes to the constitution are necessary, whereas improvements to the judicial systems are often mere administrative choices. Nevertheless, changes to investor rights do occur, often following financial and other crises. Changes in enforcement appear much more difficult over short periods of time. A number of explanations exist.

Investment in enforcement of corporate governance, and more generally in building institutions supporting market functioning, compete with other uses of government funds, including demands for redistribution and general public goods. Capacity-building is also a longer-term effort that is less visible and less politically rewarding. Finding sufficient support within the government for such efforts is thus often difficult. Public enforcement also involves several bodies. Sometimes these bodies are involved in sequence, e.g., police-courts-police, and sometimes within a hierarchy, e.g., several layers with supervisory functions (e.g., stock exchange, SEC, court). Changing multiple institutions is not only complicated, it is also costly. And in a less developed economy with limited resources and high discounting, the short-term gains may not be sufficiently large, in particular relative to competing needs in other parts of society.

Overcoming these constraints is typically also difficult since the gains from improvements in the functioning of these institutions are not distributed evenly among all citizens; in particular, large parts of the electorate may not get any direct benefits at all from increased enforcement. When strong business interests are against reform and the general population, including the poor, enjoys only limited benefits, it is hard to push through reform. With close ties between government and business, enforcement reform in the interest of minority shareholders is even less likely to see the light. Even in countries with the institutional capacity to built better enforcement, the political will is consequently often not present. Poland, for example, has a 
strong regulatory framework and ample competence in the Securities and Exchange Commission and the Warsaw Stock Exchange (Glaeser, Johnson and Shleifer, 2001), but corporate governance and its enforcement has not been very high on the political agenda leaving the bodies without the necessary political backing. In Brazil, Korea and many other middle-income countries, the capacity in SECs, Ministries of Finance and Justice, and elsewhere is often also adequate, but actual enforcement remains limited.

Thus, the level of enforcement is ultimately a matter of political priorities (Berglof and Bolton, 2003). How to build political constituencies for reform is always hard, especially when the benefits are not evenly distributed. The problem in enforcement, as in some other areas, is that there are bad equilibriums. At low levels of development, investments in enforcing rule of law may exceed the benefits they generate. Moreover, given the costs involved and the difficult priorities, the "political will" to invest in rule of law may not be present even when sufficient resources are available and the returns to investment in enforcement are high. To get out of these traps is hard. Sometimes, indirect methods can be helpful to get reforms going.

Financial development may help to increase the constituency for rule of law enforcement. Access to finance will allow more households to invest and thus strengthen the support for the protection of property rights. But financial development may also go to consumption or public investment/consumption, in both cases possibly crowding out private investment. Furthermore, if some particularly influential groups care strongly about enforcement of property rights, the outcome may be too much enforcement, at the expense of other public goods and, ultimately, growth. In many countries, the laws and judicial systems give banks much power over their borrowers, also in bankruptcy, which is not necessarily good for overall economic growth as it suppresses the emergence of new, more risky firms. Yet, reform of the bankruptcy systems in these countries has often been slow due to lobbying by the banking industry. Assuring wide access to finance is important so as to create a broader constituency for enforcement reforms. 
Another channel can be from corporate sector ownership to reform. By broadening ownership to the corporate sector to the general public should strengthen the push for reforms of enforcement. Specifically, some privatization strategies may create more support for enforcement than others (Biais and Perotti, 2001). The large-scale privatizations in Europe and the wider distribution of equity ownership have built constituencies for financial sector reform. Given large stateownership in many developing countries, say after a crisis or coming from transition, it can be useful to pursue privatization strategies aimed at widening ownership. The design of reforms and privatization strategies will be difficult, nevertheless. In many places, reforms did not go deep enough as they initially targeted the wrong issues, such as changes in laws rather than institutions, including those involved in enforcement. In Russia and the Czech Republic, for example, insiders and incumbents also hijacked the privatization and the resulting ownership structures undermined the drive for enforcement reforms (Perotti, 2002, and Cull, Matesova and Shirley, 2003).

Making enforcement a priority may also have implications for the desirability of different types of real sector reform. In particular, more competition and other external pressures can help create better property rights and greater enforcement. Perotti and Volpin (2003) develop a model in which richer entrepreneurs lobby politicians for a low level of investor protection in order to prevent potential new entrants to raise financing. They find that the degree of investor protection increases when technology or demand shocks decrease profitability and when financial integration improves access to capital. They also find that when wealth distribution becomes more equal and the country more democratic, in the sense of politicians becoming more accountable to voters, investor protection improves. Finally, they argue that large financial crises may weaken established business allowing for improvements of better protection of minority investors. 


\section{Conclusions}

While it is very difficult to draw strong conclusions, given the lack of specific research on enforcement and corporate governance, our review of the literature has highlighted some general lessons, not necessarily limited to enforcement:

- Private sector efforts to enhance enforcement are often more effective than governmentled efforts, but the two forms of enforcement often complement each other. Experience from securities regulation in the United States also suggests that private ordering can precede and serve as a basis for public laws, and private and public enforcement of these laws.

- The balance between private ordering and private enforcement of public law obviously depends on the quality of public laws and the strength of enforcing institutions. When the general enforcement environment is weak, private ordering may be the only hope. But more general evidence, at least from securities regulation, suggests that private enforcement is very important.

- Improvements in enforcement are more often the result of bottom-up approaches, rather than top-down efforts. Capacity-building is often important to support private initiatives (from rating agencies to banks) and will help build constituencies for reform.

- Top-down efforts to improve the legal and enforcement environment are difficult and rarely successful. The record of transplanting (elements) of foreign legal systems is generally not encouraging, but the experience of EU accession in Central and Eastern European countries suggests that outside anchors also can play a positive role in the implementation of reforms. 
- In designing strategies for improved enforcement of corporate governance, both the likely impact of a particular governance mechanism and the scope for improvement of this mechanism should be considered. A particular corporate governance form may play a very important role in reducing agency costs, but leave little room for improvement of enforcement, and vice versa.

The review also makes clear the limited knowledge on the issue of enforcement. A number of issues could be researched further.

- The balance between private enforcement of public standards and public enforcement. The empirical work on securities markets law shows the benefits of relying more on private means in enforcing some minority shareholder rights, disclosure and other regulations to develop capital markets. An investigation of the same issue for (other) aspects of corporate governance would be very interesting. Is private enforcement more effective than public enforcement in terms of corporate governance?

- The tradeoffs between the extensiveness of the law and its effectiveness in different contexts.

- The effectiveness of self-regulatory agencies and organizations in encouraging better standards and greater enforcement of these standards. When, for example, are stock exchanges effective in the promotion of good corporate governance? What does the move to a more for-profit status of many stock exchanges mean for the incentive structures of stock exchanges to pursue higher corporate governance standards?

- The role of competition more generally in improving the environment for enforcement.

Both case studies and cross-country research are necessary to shed light on these issues. 


\section{References}

Acemoglu, Daron, Simon Johnson, and James A. Robinson. 2001. The colonial origins of comparative development: an empirical investigation, American Economic Review 91, 13691401 .

Acemoglu, D., S. Johnson, J. Robinson, and Y. Thaicharoen. 2003. Institutional Causes, Macroeconomic Symptoms: Volatility, Crises and Growth. Journal of Monetary Economics Netherlands 50 1, 49-131.

Acemoglu, Daron, and Thierry Verdier. 2000. The Choice Between Market Failures and Corruption, March, American Economic Review Papers and Proceedings, volume 90, pp. 194211.

Barth, James R., Gerard Caprio Jr., and Ross Levine. 2004. Bank Regulation and Supervision: What Works Best? Journal of Financial Intermediation, Volume 13, Issue 2, April, Pages 205248.

Becht, Marco, Patrick Bolton, and Alisa Röell. 2003. Corporate Governance and Control. In George Constantinides, Milton Harris, and René Stulz, eds. Handbook of the Economics of Finance. Amsterdam: North-Holland.

Beck, Thorsten, Asli Demirgüç-Kunt, and Ross Levine. 2003. "Law, Endowments, and Finance.” Journal of Financial Economics. Netherlands; 70, No. 2:137-81. November.

Beck, Thorsten, Asli Demirgüç-Kunt, and Vojislav Maksimovic. 2002. "Financial and Legal Constraints to Firm Growth: Does Size Matter?” World Bank Policy Research Working Paper; No. 2784. Washington, D.C.

Becker, Gary. 1968. Crime and Punishment: An Economic Approach, Journal of Political Economy 76, 169-217.

Berglof, Erik, and Patrick Bolton. 2002. The Great Divide and Beyond: Financial Architecture in Transition. Journal of Economic Perspectives 16, Winter, 77-100.

Berglöf, E. and P. Bolton. 2003. Law Enforcement, Fiscal responsibility and Financial Development, mimeo, Princeton University.

Berglof, E., and A. Pajuste. 2003. Corporate Governance in Central and Eastern Europe, in P. Cornelius and B. Kogut, Global Competitiveness and Corporate Governance, Oxford University Press.

Berglöf, E., M. Burkart and G. Friebel. 2003. Clubs-in-Clubs - Enforcement Under Unanimity, mimeo, SITE, Stockholm School of Economics. 
Berglöf, E. and Ernst-Ludwig von Thadden. 2000. The Changing Corporate Governance Paradigm, in Pleskovic and Stiglitz eds. World Development Conference, The World Bank.

Berkowitz, Dan, Katharina Pistor, and Jean-Francois Richard. 2003. Economic Development, Legality, and the Transplant Effect. European Economic Review 47,165-195.

Besley, Timothy.1995. Property Rights and Investment Incentives: Theory and Evidence from Ghana, Journal of Political Economy, Vol. 103, pp. 903-937.

Bhattacharya, Utpal, and Hazem Daouk. 2002. The world price of insider trading, Journal of Finance 57, 75-108.

Biais, B., and E. Perotti. 2002. Machiavellian Privatization. American Economic Review 92 March, 240-48.

Black, Bernard. 2001. The Legal and Institutional Preconditions for Strong Securities Markets, UCLA Law Review 48, 781-858.

Black, Bernard. 2001. The Corporate Governance Behavior and Market Value of Russian Firms. Emerging Markets Review 2, 89-108.

Black, Bernard, Hasung Jang and Woochan Kim. 2003. Does Corporate Governance Affect Firms' Market Values? Evidence from Korea, working paper, at http://ssrn.com/abstract=311275

Black, Bernard and Reinier Kraakman. 1996. A Self-Enforcing Model of Company Law, Harvard Law Review vol. 109, pp. 1911-1981

Black, Bernard, Reinier Kraakman, and Anna Tarassova. 2000. Russian Privatization and Corporate Governance: What Went Wrong? Stanford Law Review 525,1731-1808.

Black, Bernard, and Reinier Kraakman. 1996. A Self-Enforcing Model of Corporate Law, with Bernard Black, Harvard Law Review, 109, 1911- 1982.

Demirguc-Kunt, Asli, and Vojislav Maksimovic. 1998. Law, Finance, and Firm Growth, Journal of Finance, 53, 2107-2137.

Broadman, Harry G. 1999. Reducing Structural Dominance and Entry Barriers in Russian Industry, in Russian Enterprise Reform, Harry G. Broadman ed., World Bank Discussion Paper No. 400

Claessens, Stijn. 2003. Corporate governance and development, 2003, in Focus 1: Corporate Governance and Development, World Bank, Washington, D.C.

Coffee, John C. Jr. 1999. The Future as History: The Prospects for Global Convergence in Corporate Governance and its Implications, Northwestern Law Review 93, 641-707. 
Coffee, John Jr. 2002. Racing Towards the Top? The Impact of Cross-Listings and Stock Market Competition on International Corporate Governance. Columbia Law Review 102 7,1757-1831.

Cooter, Robert, D. 1991. Economic Theories of Legal Liability, Journal of Economic Perspectives, v5, no 3, p. 11.

Cull, Robert, Jana Matesova and Mary M. Shirley. 2003. Ownership and the Temptation to Loot: Evidence from Privatized Firms in the Czech Republic, Journal of Comparative Economics, Vol. 30, No. 1 pp. 1-24.

Defond, Mark L., and Mingyi Hung. 2003. Investor Protection and Corporate Governance: Evidence from Worldwide CEO Turnover, mimeo, University of Southern California - Leventhal School of Accounting.

Dixit, Avinash. Forthcoming. Lawlessnes and Economics: Alternative Modes of Governance, The Gorman Lecture, Princeton University Press, Princeton.

Djankov, Simeon, Edward L. Glaeser, Rafael La Porta, Florencio López-de-Silanes, and Andrei Shleifer. 2003. The New Comparative Economics. Journal of Comparative Economics.

Djankov, Simeon, Rafael La Porta, Florencio Lopez-de-Silanes, and Andrei Shleifer. 2003. Courts The Quarterly Journal of Economics, 118, 453-517.

Durnev, A., and E. H. Kim. 2002. To Steal or Not to Steal: Firm Attributes, Legal Environment, and Valuation, mimeo. University of Michigan Business School, Ann Arbor.

Dyck, Alexander and Luigi Zingales. 2003. The Corporate Governance Role of the Media in R. Islam ed. The right to tell: The role of the Media in Development, The World Bank, Washington DC, 2002.

Ellickson, R.C. 1991. Order Without Law, Harvard Univ. Press, Cambridge, MA.

Gambetta, Diego. 1993. The Sicilian Mafia: The Business of Private Protection. Cambridge, MA: Harvard University Press.

Foley, Fritz. 2000. Going Bust in Bangkok: Lessons from Bankruptcy Law Reform in Thailand, mimeo, Harvard University.

Gibbons, Michael. 2002. Is Corporate Governance Ineffective in Emerging Markets? The Journal of Financial and Quantitative Analysis, Special Issue on International Corporate Governance.

Glaeser, Ewards, Simon Johnson, Andrei Shleifer. 2001. Coase versus the Coasians, Quarterly Journal of Economics U.S.; 116, No. 3:853-99, August. 
Glaeser, Edward and Andrei Shleifer. 2001. A Reason for Quantity Regulation, American Economic Review Papers and Proceedings 91, 431-435.

Glaeser, Edward and Andrei Shleifer. 2002. Legal Origins, Quarterly Journal of Economics November

Glaeser, Edward, Jose Sheinkman, and Andrei Shleifer. 2003. Injustice of Inequality, Journal of Monetary Economics: Carnegie-Rochester Series on Public Policy, January.

Gregory, Holly J. 2000. International Comparison of Corporate Governance: Guidelines and Codes of Best Practice in Developing and Emerging Markets, Weil, Gotshal \& Manges LLP. . 2001. International Comparison of Corporate Governance: Guidelines and Codes of Best Practice in Developed Markets, Weil, Gotshal \& Manges LLP.

Greif, Avner. 1993. Contract Enforceability and Economic Institutions in Early Trade: the Maghribi Traders' Coalition, American Economic Review, 833 pp. 525-48.

Greif, Avner. 1992. Institutions and International Trade: Lessons from the Commercial Revolution, American Economic Review, 822 pp. 128-33.

1993. Contract Enforceability and Economic Institutions in Early Trade: The Maghribi Traders' Coalition, American Economic Review, 525-584.

Greif, Avner, Paul Milgrom, and Barry Weingast. 1994. Coordination, Commitment, and Enforcement: The Case of the Merchant Guild, The Journal of Political Economy, vol. 102, no. $4,745-777$.

Guriev, Sergei, Olga Lazareva, Andrei Rachinsky and Sergei Tsukhlo. 2003. Corporate Governance in Russian Industry, working paper, CEFIR, Moscow.

Hay, Jonathan R., Andrei Shleifer and Robert Vishny. 1996. Toward a Theory of Legal Reform, European Economic Review 40, 559-567.

Hauswald, Robert and Hege, Ulrich. 2003. Ownership and Control in Joint Ventures: Theory and Evidence. CEPR Discussion Papers 4056.

Immordino, Giovanni and Marco Pagano. 2003. Design and Enforcement of Legal Standards, CSEF Working Papers 98, Centre for Studies in Economics and Finance CSEF, University of Salerno, Italy.

Jappelli, Tullio, Marco Pagano and Magda Bianco. 2002. Courts and Banks: Effects of Judicial Enforcement on Credit Markets, CEPR Working Paper No. 3347. 
Kaplan, S. 1994. Top Executives Turnover and Firm Performance in Germany, Journal of Law, Economics and Organization, 10, 142-159.

Kang, J. and A. Shivdasani. 1995. Firm Performance, Corporate Governance, and Top Executive Turnover in Japan, Journal of Financial Economics, 38, 29-58.

Klapper, Leora F. and Inessa Love. 2003. Corporate Governance, Investor Protection and Performance in Emerging Markets, Journal of Corporate Finance, forthcoming, at http://ssrn.com/abstract=303979.

La Porta, Rafael, Florencio Lopez-De-Silanes, and Andrei Shleifer. 1999. Corporate Ownership around the World. Journal of Finance 54 2, 471-518.

La Porta, Rafael, Florencio Lopez-de-Silanes, Andrei Shleifer, and Robert Vishny. 1997. Legal Determinants of External Finance. Journal of Finance 52 3, 1131-50.

La Porta, Rafael, Florencio Lopez-de-Silanes, Andrei Shleifer, and Robert Vishny. 1998. Law and Finance. Journal of Political Economy 106 6, 1113-55.

La Porta, Rafael, Florencio Lopez-de-Silanes, Andrei Shleifer, and Robert Vishny. 2002. Investor Protection and Corporate Valuation. Journal of Finance 57 3, 1147-70.

La Porta, Rafael, Florencio Lopez de-Silanes, and Andrei Shleifer. 2003. What Works in Securities Laws, NBER Working Paper 9982.

Lopez-de-Silanes, Florencio. 2003. A Survey of Securities Laws and Enforcement, Discussion Paper, Global Corporate Governance Forum, No. 2, Washington, D.C.

Laeven, Luc and Christopher Woodruff. 2003. The Quality of the Legal System, Firm Ownership, and Firm Size, World Bank and the Graduate School of International Relations and Pacific Studies, UCSD, mimeo.

Licht, Amir. 2003. Cross-Listing and Corporate Governance: Bonding or Avoiding?, 4 Chicago Journal of International Law. 141.

McMillan, John and Christopher Woodruff. 1999. Dispute Prevention without Courts in Vietnam, Journal of Law, Economics and Organization, 153, pp. 637-658.

Milhaupt, Curtis J. 2003. Nonprofit Organizations as Investor Protection: Economic Theory, and Evidence from East Asia, March, Mimeo, Columbia University.

Morck, Randall and Bernard Yeung. 2003. Corporate Governance and Family Control, Discussion Paper 1, Global Corporate Governance Forum, Washington, D.C. 
Nenova, Tatiana. 2001. Control Values and Changes in Corporate Law in Brazil September 25. EFMA 2002 London Meetings.

North, Douglass C. 1991. Institutions, Institutional Change, and Economic Performance. Cambridge: Cambridge University Press.

OECD. 2003. Experiences from the Regional Corporate Governance Roundtables, Paris.

Ostrom, Elinor. 1990. "The Nature of Common-Pool Resource Problems," with Roy Gardner and James Walker. Rationality and Society, Vol. 2, No. 3 July 1990, 335-358.

Perotti, Enrico. 2002. Lessons from the Russian Meltdown: The Economics of Soft Legal Constraints, CEPR Policy Paper 9: London, UK.

Perotti, Enrico and PaoloVolpin. 2003. The Political Economy of Entry: Lobbying, Inequality and Financial Development CEPR Working Paper.

Persson and Tabellini. 2003. Political Economics, Explaining Economic Policy, Cambridge: The MIT Press.

Pinheiro Castelar, Armand and Celia Cabral. 2001. Credit Markets in Brazil: The Role of Enforcement and Other Institutions, In Marco Pagano ed. Defusing Default, Inter-American Development Bank and OECD, Washington, D.C., 157-188.

Pistor, Katharina, Martin Raiser, and Stanislav Gelfer. 2000. Law and Finance in Transition Economies. The Economics of Transition 8 2, 325-368.

Pistor, Katharina and Chenggang Xu. 2003. Incomplete Law - A Conceptual and Analytical Framework - And its Application to the Evolution of Financial Market Regulation. April. Mimeo, Columbia University.

Polinsky, Mitchell and Steven Shavell. 2000. The Economic Theory of Public Enforcement of Law, Journal of Economic Literature 38, 45-76.

Rossi, Stefano, and Paolo Volpin. 2003. Cross-Country Determinants of Mergers and Acquisitions. Working Paper 3889. Centre for Economic Policy Research, London.

Rubin, Paul. 1994. "'Growing a Legal System in the Post-Communist Economies, Cornell International Law Journal, Vol. 27, 1-47.

Shleifer, Andrei, and Robert Vishny. 1997. A Survey of Corporate Governance. Journal of Finance 52 2, 737-83.

Siegel, Jordan I. 2004. "Can Foreign Firms Bond Themselves Effectively by Renting U.S. Securities Laws?" Journal of Financial Economics, forthcoming. 
Slinko, Irina, Yevgeny Yakovlev and Ekaterina Zhuravskaya. 2002. State Capture in the Russian Regions, CEFIR working paper.

Stulz, René, and Rohan Williamson. 2003. Culture, Openness, and Finance, Journal of Financial Economics, V70(3), 313-349. December.

Zhuravskaya, Ekaterina and Oleg Zamulin. 2003. Administrative Barriers to Small Business in Russia: Results from a New Survey, CEFIR working paper, at http://www.cefir.org/papers_academic.html. 